\title{
Use of Plant Bioassays for Assessing Mine Tailings Rehabilitation Strategies
}

\author{
Mariagrazia Proto ${ }^{1}$, Ronan Courtney ${ }^{1}$ \\ ${ }^{1}$ University of Limerick, Department of Biological Sciences and Bernal Institute \\ Castletroy Park, Limerick \\ mariagrazia.proto@ul.ie; ronan.courtney@ul.ie
}

\section{Extended Abstract}

Metalliferous mining is an important economic activity [1] [2] although it produces a large amount of mineral waste (i.e. several thousand million tons per year) that is divided into two distinct physical forms:

$>$ Coarse waste rock: usually with a diameter of 2-20 cm [3] [4]

$>$ Tailings: fine-grained with a diameter $<2.0 \mathrm{~mm} \mathrm{[4]}$

Disposal and containment of metalliferous mine tailings can result in severe pollution and have aesthetic impacts on the local environment. Creating a vegetation cover on tailings is viewed as an effective strategy for stabilising and reclaiming tailings. Many strategies are available for the remediation of the metalliferous sites, such as physical stabilization, which consists of covering the tailings with an innocuous material, and chemical stabilization, which consists in adding a chemical agent to the tailings able to absorb the pollution [3]. However only with the application of phytoremediation strategies (biological stabilization), it is possible to establish if the remediation is effective and long-term. The phytoremediation of the mine tailings is effective in providing surface stability to prevent the wind-blow of contaminated particulates and in reducing water pollution. Although the phytoremediation is desirable, for several reasons, such as reduced costs compared to conventional remediation techniques, easy monitoring and a high degree of social acceptability, metalliferous wastes are an unfavourable environment for plant growth due to the many growth-limiting factors such as poor water-holding, deficiency of macronutrients and potentially high levels of heavy metals. [5] [6] [7]

Samples of historic (not remediated) $\mathrm{Pb} / \mathrm{Zn}$ mine tailing from Ireland and $\mathrm{UK}$ were collected in order to assess the metal uptake risk in plants [8]. Tailings were characterized for $\mathrm{pH}, \mathrm{EC}$, and the different fractions (soluble, available and total) of metal concentration (using $\mathrm{H}_{2} \mathrm{O}, 0.1 \mathrm{M} \mathrm{CaCl}_{2}$ and aqua regia). The growth of the Lolium perenne was evaluated using the Rhizotest $^{\mathrm{TM}}$; and the uptake of essential elements ( $\mathrm{Ca}$, and $\mathrm{Mg}$ ) and of heavy metals ( $\mathrm{Sb}, \mathrm{As}, \mathrm{Cd}, \mathrm{Cr}, \mathrm{Fe}, \mathrm{Mn}, \mathrm{Ni}, \mathrm{Pb}, \mathrm{Zn}$ ) was determined both in the shoots and in the roots.

Finally, the Phytotoxkit ${ }^{\mathrm{TM}}$ was used to assess the effects of the remediation treatments on the germination and on the seedling growth of the plant. All the samples were treated with a different amount (percentage) of control soil (i.e. 100\% tailings; $80 \%$ tailing-20\% control-soil; $60 \%$ tailings- $40 \%$ control-soil; until 100\% control-soil) using the seeds of Lepidium sativum. It was observed that the $100 \%$ mine tailings (not treated) severely inhibits the germination and the growth of the plants. The results obtained by the Phytotoxkit show the decrease of percentage inhibition of plant growth (either in roots and shoots) increasing the amount of control soil.

\section{References}

[1] X. Zhang, L. Yang, . Y. Li , H. Li , W. Wang and . B. Ye, "Impacts of lead/zinc mining and smelting," Environ Monit Assess, vol. 184, pp. 2261-2273, 2012.

[2] S. Enlhazaya, K. Ohe, B. Shimori, B. Oyuntsetseg, O. Bayanjergal and M. Watanabe, "Assessment of heavy metals in mining tailings around Boroo and Zuunkharaa gold mining areas of Mongolia," Journal of Environmental Science and Technology, pp. 379-389, 2015.

[3] G. M. Tordoff, A. J. Baker and A. J. Willis, "Current approaches to the revegetation and reclamation of metalliferous mine wastes," Chemosphere, vol. 41, pp. 219-228, 2000. 
[4] S. Callery and R. Courtney, "Assessing metal transfer to vegetation and grazers on reclaimed pyritic $\mathrm{Zn}$ and $\mathrm{Pb}$ tailings.," Environmental science and pollution research, vol. 22, pp. 19746-19772, 2015.

[5] Z. H. Ye, W. S. Shu, Z. Q. Zhang, C. Y. Lan and M. H. Wong, "Evaluation of the application of dry covers over carbonate-rich sulphide tailings," Chemosphere, vol. 47, pp. 1103-1111, 2002.

[6] E. Moreno-Jimenez, J. M. Penalosa, R. Manzano, R. O. Carpena-Ruiz, R. Gamarra and E. Esteban, "Heavy metals distribution in soils surrounding an abandoned mine in NW," Journal of Hazardous Materials, vol. 162, pp. 854-859, 2009.

[7] D. Brennan, B. Coulter, G. Mullen and R. Courtney, "Evaluation of Mehlich 3 for Extraction of Copper and Zinc from Irish Grassland Soils and for Prediction of Herbage Content," Communications in Soil Science and Plant Analysis,, vol. 39, pp. 1943-1962, 2008.

[8] E. Di Carlo, A. Boullemant and R. Courtney, "Ecotoxicological risk assesment of revegetated bauxite residue: Implication for future rehabilitation programme," Science of the total environment, vol. 698, 2020. 